Proc. Estonian Acad. Sci. Biol. Ecol., 2003, 52, 3, 205-217

\title{
Does excessive phosphorus necessarily cause increasing biomass of diazotrophic cyanobacteria?
}

\author{
Andres Jaanus ${ }^{\mathrm{a}^{*}}$ and Katja Pellikka ${ }^{\mathrm{b}}$ \\ ${ }^{\text {a }}$ Estonian Marine Institute, University of Tartu, Marja 4D, 10617 Tallinn, Estonia \\ ${ }^{\mathrm{b}}$ City of Helsinki Environment Centre, P.O.BOX 500, 00099 Helsinki, Finland.
}

Received 10 December 2002, in revised form 28 May 2003

\begin{abstract}
The influence of increasing phoshporus $\left(\mathrm{PO}_{4}-\mathrm{P}\right)$ on the biomass and composition of diazotrophic ( $\mathrm{N}_{2}$-fixing) cyanobacteria was evaluated on the ground of 6-year (1997-2002) intensive monitoring data, collected from the ship route between Tallinn and Helsinki (central Gulf of Finland). Phytoplankton biomass estimations were performed weekly from 15 June to 31 July to obtain the magnitude of cyanobacterial dominance, and the results were related to inorganic nutrient residual concentrations left from spring bloom. We could not find any strong relationships between cyanobacterial biomass and pre-bloom $\mathrm{PO}_{4}-\mathrm{P}$ concentrations or the $\mathrm{N}$ : P ratio. In 1997 and 2002, the years of exceptional summer blooms, the mass development of Aphanizomenon flos-aquae was likely a response to short-time nutrient pulses accompanied with upwelling and/or other hydrodynamical forcing. Nodularia spumigena formed only local short-time blooms in 1999 and 2001 , when the phosphorus concentration was at its lowest $(<0.1 \mu \mathrm{M})$. It is the favourable nutrient conditions preceding the most intensive development of cyanobacterial bloom that determine the magnitude of biomass growth rather than the situation after the spring bloom decline.
\end{abstract}

Key words: Gulf of Finland, nutrients, cyanobacterial blooms.

\section{INTRODUCTION}

Excessive phosphorus loading accompanying urban, industrial, and agricultural expansion, which started early in the 20th century, has often been related to the blooms of heterocystous cyanobacteria (e.g. Horstmann, 1975; Niemi, 1979). These algae are able to form nuisance, unaesthetic surface accumulations

* Corresponding author, andres@phys.sea.ee 
and cause hypoxia-anoxia in vertically stratified basins underlying blooms. Since the late 1960s, P inputs have fallen in the Baltic; however, periods of bottomwater hypoxia and anoxia have persisted. Despite the decrease in loading, an increase in the phosphate-P concentrations was observed both in the surface and near-bottom layers around the mid-1990s. The most probable reason for this development was considered to be the acceleration of internal loading (Pitkänen et al., 2001). Continued periodic bottom-water anoxia has led to episodic release of sediment $\mathrm{P}$ into the water column, arguably supporting additional Aphanizomenon and Nodularia blooms (Paerl, 1997). On the other hand, oxygen deficiencies were observed already at the end of the 19th century in the Baltic deep basins, despite the much lower nutrient loading and primary production (Wulff et al., 1990). Although weather conditions and high nutrient loads were cited as an explanation for the mass development of cyanobacteria at the beginning of the 20th century, the blooms have been common since the 1960s in the open sea in both the Baltic Proper and the Gulf of Finland (Finni et al., 2001). The absence of intensive Nodularia blooms during the late 1980s and early 1990s have been in turn attributed to the increased nitrogen loading with accompanying increase in the $\mathrm{N}: \mathrm{P}$ ratio (Kononen, 1992).

From this, the increased P-concentrations should lead to a descending N:P ratio and favour mass developments of diazotrophic $\left(\mathrm{N}_{2}\right.$-fixing) cyanobacteria, especially of the potentially toxic species Nodularia spumigena. On the basis of intensive phytoplankton monitoring data, collected from the ship route between Tallinn and Helsinki (central Gulf of Finland) we try to evaluate whether the increase in bioavailable phosphate-P concentrations is an inevitable prerequisite for the enhancement of nitrogen-fixing cyanobacterial biomass. Making conclusions, we still bear in mind that in the current ecological literature the nutrient effect on phytoplankton is rather multiple and a stochastic result of the combination of environmental factors (Hecky \& Kilham, 1988; Sterner, 1994; Reynolds et al., 2000).

\section{MATERIAL AND METHODS}

\section{Study site and sampling}

The material was collected on the ship route from Tallinn to Helsinki on board the passenger ferries Wasa Queen (in 1997-98) and Finnjet (in 1999-2002). The location of the sampling stations along the route is shown in Fig. 1. An automatic refrigerated water sampler by ISCO conducted water sampling for chemical and phytoplankton analyses. The sampling depth was $\sim 5 \mathrm{~m}$, but the sampling water is assumed to represent mixed surface water because of mixing caused by the ferry. Samples for phytoplankton biomass determination were taken weekly during the vegetation period from April to October. Nutrient analyses were performed 


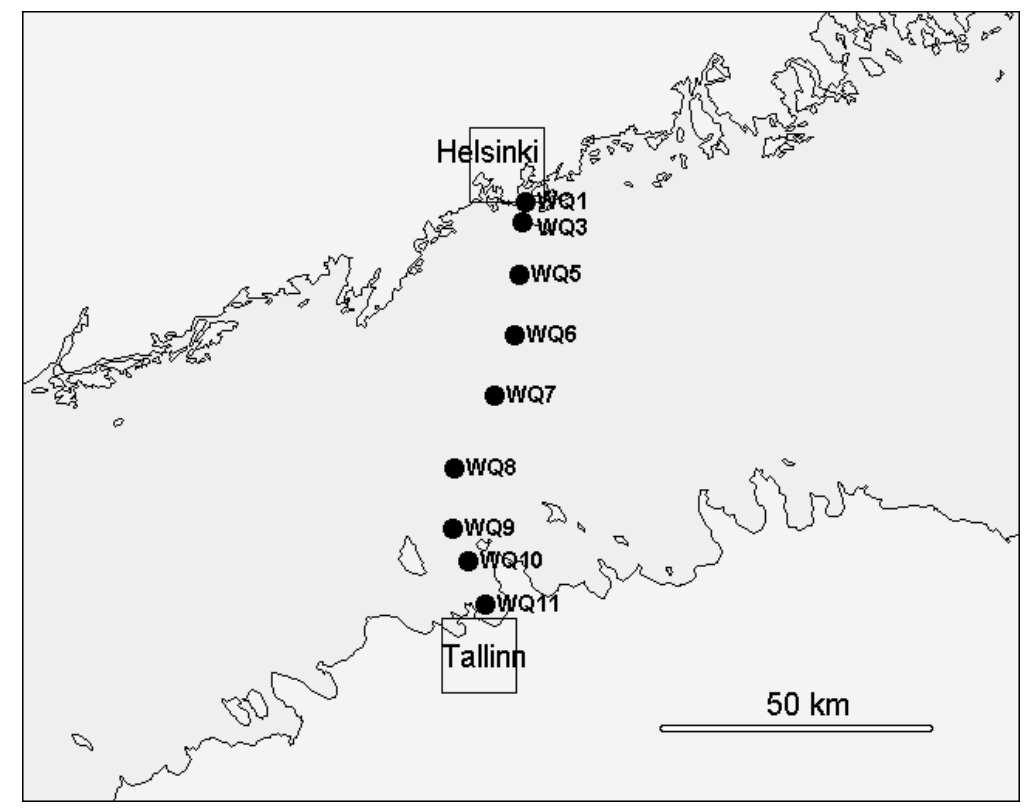

Fig. 1. The study area with sampling stations.

weekly to fortnightly during the spring period and 1-2 times a month during summer and autumn. The period for phytoplankton data analysis was restricted from 15 June to 31 July (248 samples from seven stations), most likely representing summer communities in the Gulf of Finland.

\section{Temperature and nutrients}

Water temperature was measured at the $\sim 5 \mathrm{~m}$ depth in $\sim 100 \mathrm{~m}$ intervals with an Anderaa temperature sensor. The nutrient analyses were performed by the City of Helsinki Environment Laboratory and Uusimaa Regional Environmental Centre Laboratory. Inorganic nitrogen and phosphorus were analysed according to standard methods of the Finnish Standards Association SFS (SFS-EN ISO 13395, 1997; SFS 3025, 1986).

\section{Phytoplankton}

Samples (100-200 mL) for quantitative phytoplankton analysis were fixed with acetic Lugol's solution to a final concentration of $0.2-0.5 \%$ and counted under the inverted microscopes Olympus IM, Olympus IMT-2, and Leitz Fluovert using $\times 200-400$ magnifications. Wet weight biomass of phytoplankton 
was calculated from cell geometry (HELCOM, 1988; Hillebrand et al., 1999) and using cell volume tables (Phyto, Software Kahma Ky) or after original measurements.

Statistical treatment of the data was performed by using two-way ANOVA and multiple regression analysis. Analysed data followed the assumptions of normality (the Kolmogorov-Smirnov test for goodness of fit) and homoscedasticity (Bartlett's and Hartley's tests).

\section{RESULTS}

\section{Hydrometeorological conditions}

During the investigation period, four warmer (in 1997, 1999, 2001, and 2002) and two cooler summers (in 1998 and 2000) could be distinguished (Table 1). Usually, the temperature maximums were recorded in the second half of July.

Table 1. Seasonal (15 June to 31 July) minimum, average, and maximum temperatures at the $\sim 5 \mathrm{~m}$ depth along the sampling route

\begin{tabular}{lcc|c|c|c|c}
\hline & 1997 & 1998 & 1999 & 2000 & 2001 & 2002 \\
\hline $\begin{array}{l}\text { Minimum } T \\
{ }^{\circ} \mathrm{C}\end{array}$ & 11.7 & 11.2 & 13.4 & 8.9 & 9.7 & 10.1 \\
$\quad$ Date & 13.07 & 21.06 & 15.06 & 15.06 & 19.06 & 13.06 \\
$\quad$ Station & WQ11 & WQ7 & WQ5 & WQ5 & WQ7 & WQ11 \\
Average $T,{ }^{\circ} \mathrm{C}$ & 16.9 & 14.7 & 18.2 & 15.0 & 16.7 & 16.3 \\
Maximum $T$ & & & & & & \\
${ }^{\circ} \mathrm{C}$ & 21.6 & 17.2 & 22.3 & 18.3 & 22.7 & 21.1 \\
Date & 27.07 & 27.07 & 18.07 & 06.07 & 26.07 & 18.07 \\
Station & WQ1 & WQ11 & WQ11 & WQ5 & WQ5 & WQ9
\end{tabular}

\section{Variation of nutrient concentrations}

A large seasonal variation, characterized by high autumn and winter and low summer concentrations, was recorded for both inorganic nitrogen and phosphorus. However, the concentrations of nutrients, especially inorganic nitrogen, increased gradually towards the northern part of the route, being at the highest level in the Helsinki sea area (Fig. 2). The concentrations of inorganic phosphorus were distributed more evenly and followed a similar seasonal pattern along the study area. The DIN: DIP ratio was mainly below the Redfield molar ratio $(\mathrm{N}: \mathrm{P}=16: 1)$, 

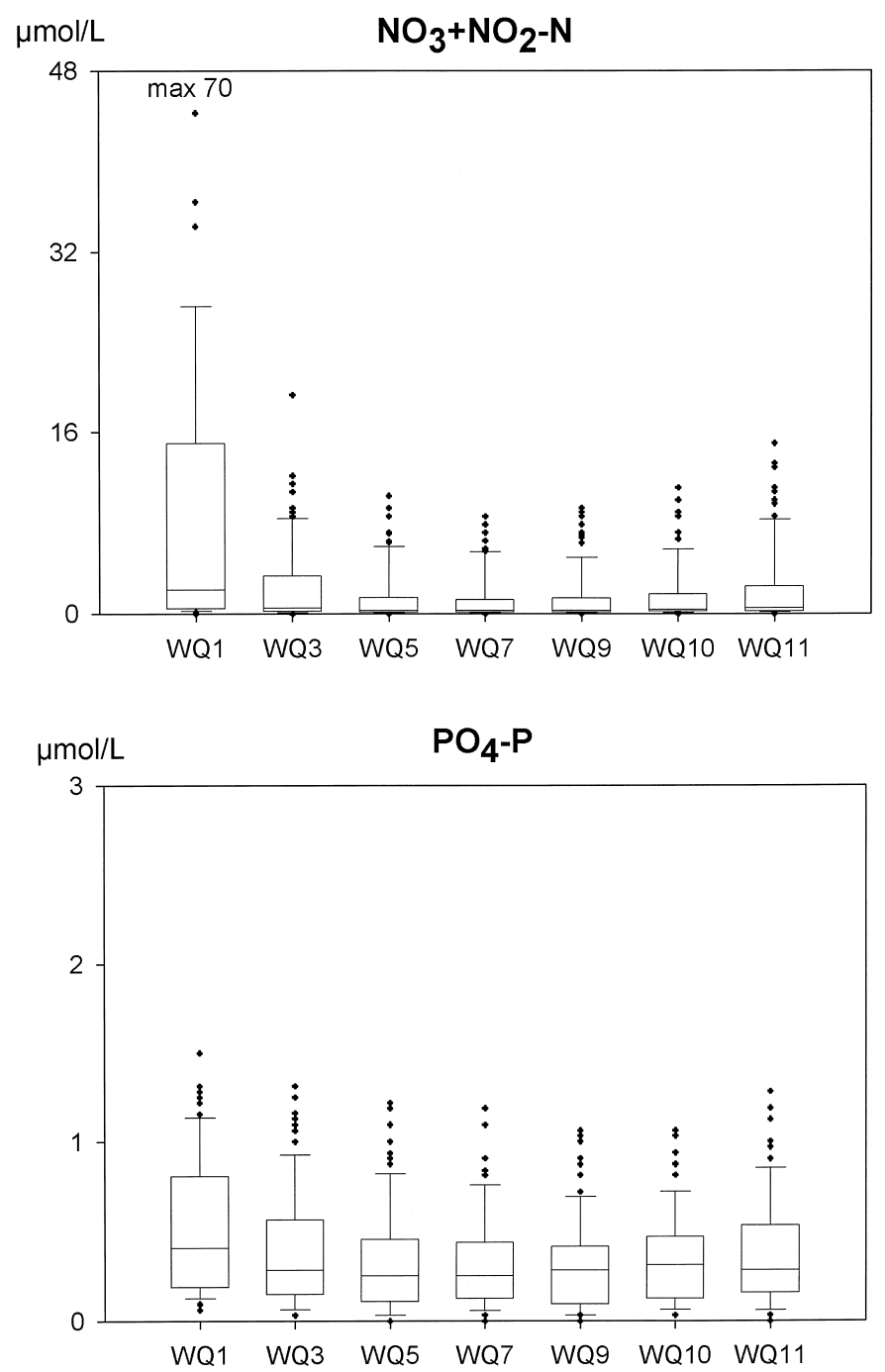

Fig. 2. Variability in nitrate-nitrite $\left(\mathrm{NO}_{3}+\mathrm{NO}_{2}-\mathrm{N}\right)$ and phosphate $\left(\mathrm{PO}_{4}-\mathrm{P}\right)$ concentrations at the sampling sites.

except at station WQ1, where it was up to 50-100:1 during the winter period. During the summer period, this ratio remained very low (0.3-6.9) at mostly low concentrations of both inorganic nitrogen and phosphorus $\left(<1 \mu \mathrm{mol} \mathrm{L}^{-1}\right)$.

The drop in nutrient concentrations after the spring bloom was recognized and the onset of cyanobacterial dominance was found from the phytoplankton quantitative data. The results indicated higher concentrations for $\mathrm{PO}_{4}-\mathrm{P}$ after the spring bloom in 1997 and 2002, but also for $\mathrm{NO}_{3}+\mathrm{NO}_{2}-\mathrm{N}$ in the southern part of the gulf in 2002 (Table 2). 
Table 2. Concentrations of inorganic phosphorus and nitrogen $\left(\mathrm{PO}_{4}-\mathrm{P}\right.$ and $\left.\mathrm{NO}_{3}+\mathrm{NO}_{2}-\mathrm{N}, \mu \mathrm{mol} \mathrm{L} \mathrm{L}^{-1}\right)$ measured before the onset of cyanobacterial growth along the Helsinki-Tallinn ferry route in 1997-2002

\begin{tabular}{l|lll|c|c|c|c|c|c}
\hline \multirow{2}{*}{ Year } & \multicolumn{7}{c}{ Station } \\
\cline { 2 - 9 } & WQ1 & WQ3 & WQ5 & WQ7 & WQ9 & WQ10 & WQ11 & Mean \\
\hline \multicolumn{7}{|c}{ Phosphorus } \\
1997 & 0.72 & 0.28 & 0.22 & 0.53 & 0.50 & 0.34 & 0.28 & 0.41 \\
1998 & 0.44 & 0.22 & 0.25 & 0.28 & 0.22 & 0.22 & 0.28 & 0.27 \\
1999 & 0.22 & 0.22 & 0.06 & 0.13 & 0.06 & 0.06 & 0.06 & 0.12 \\
2000 & 0.31 & 0.34 & 0.16 & 0.06 & 0.06 & 0.13 & 0.09 & 0.17 \\
2001 & 0.09 & 0.06 & 0.03 & 0.06 & 0.06 & 0.09 & 0.16 & 0.08 \\
2002 & 0.34 & 0.25 & 0.22 & 0.28 & 0.53 & 0.47 & 0.75 & 0.41 \\
& & & & & & & & & \\
1997 & 0.86 & 0.64 & 0.29 & 0.36 & 0.21 & 0.14 & 0.21 & 0.39 \\
1998 & 2.00 & 0.36 & 0.14 & 0.14 & 0.14 & 0.21 & 0.36 & 0.48 \\
1999 & 0.86 & 0.57 & 0.43 & 0.29 & 0.07 & 0.14 & 0.21 & 0.37 \\
2000 & 0.43 & 0.21 & 0.29 & 0.29 & 0.43 & 0.29 & 0.36 & 0.33 \\
2001 & 2.21 & 0.21 & 0.21 & 0.21 & 0.21 & 0.21 & 0.43 & 0.53 \\
2002 & 0.14 & 0.07 & 0.07 & 0.07 & 1.57 & 1.00 & 3.14 & 0.87
\end{tabular}

\section{Dynamics of cyanobacteria}

The onset of cyanobacterial biomass growth was observed 2-5 weeks after the decline of the spring bloom (7 June to 13 July), mainly depending on the hydrometeorological conditions. Usually the cyanobacterial dominance was first recorded in Tallinn Bay and at last in the Helsinki sea area, but in 2002 it was observed earlier in the northern and central parts of the route than at the southern stations (on 13 and 27 June, respectively). A sharp temperature drop was observed in the surface layer (from $10-11$ to $5-6^{\circ} \mathrm{C}$ ) at the end of May in the southern part of the gulf, which probably restrained the onset of the cyanobacterial bloom. Elevated nutrient concentrations (see above) accompanied with a temperature fall probably refer to an upwelling of nutrient-rich water. The intensive biomass growth of filamentous cyanobacteria Aphanizomenon flosaquae started at water temperatures of $14-18^{\circ} \mathrm{C}$. Exceptionally, in 2001, the water temperature at the $5 \mathrm{~m}$ depth was only $10-12^{\circ} \mathrm{C}$ when Aphanizomenon became dominant in phytoplankton.

In most cases the cyanobacterial biomass maximum developed during 2-3 weeks from the beginning of their dominance in phytoplankton. The biomass of nitrogen-fixing cyanobacteria consisted mainly of A. flos-aquae (Fig. 3a). On average, the share of Nodularia spumigena did not exceed 10-20\% of the total biomass. Short-time maxima of $N$. spumigena with relative biomass up to $90 \%$ were recorded only at single stations in 1997, 1999, and 2001, contributing still up to $30-50 \%$ of the total summer average (Fig. 3b). The maxima of $N$. spumigena coincided with a rapid increase in the surface layer temperature above $18^{\circ} \mathrm{C}$ and calm periods. 
(a)

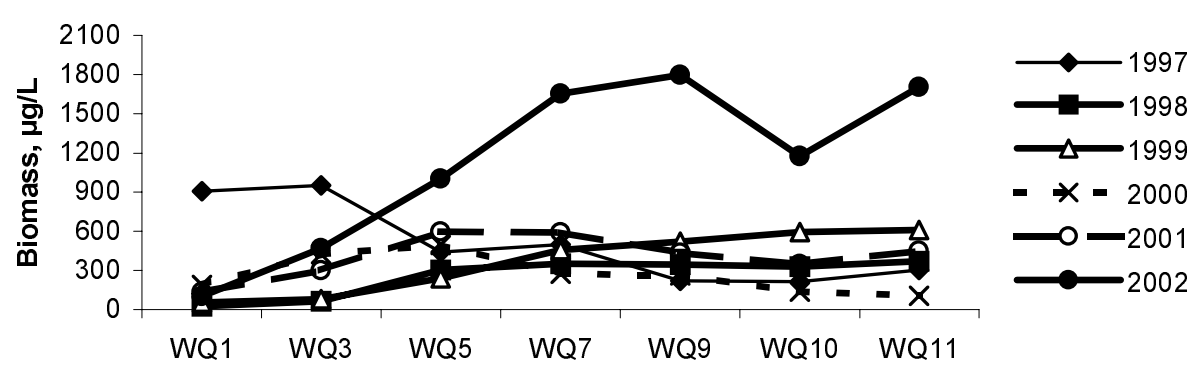

(b)

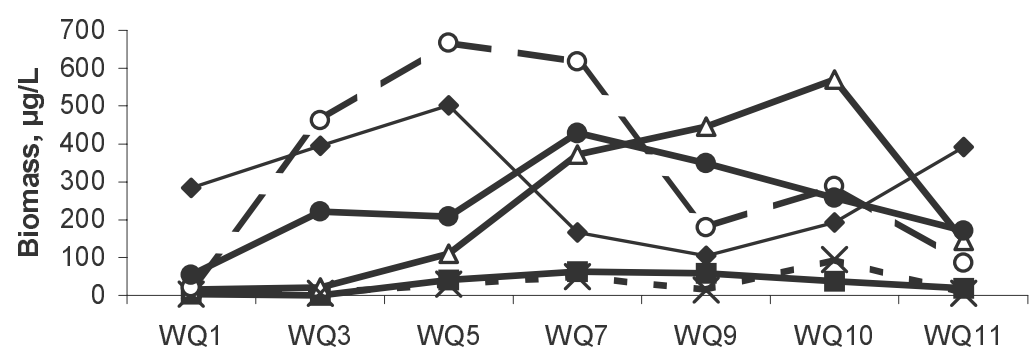

Fig. 3. Averaged seasonal (15 June to 31 July) biomass of Aphanizomenon flos-aquae (a) and Nodularia spumigena (b).

The third biomass-forming nitrogen-fixing species Anabaena lemmermannii and other Anabaena species played a minor role. Only on 6 July 1997 their contribution to the total cyanobacterial biomass was measured to form up to $30 \%$ in Tallinn Bay, but remained insignificant in most cases.

As a rule, one pronounced cyanobacterial biomass maximum was recorded during the summer, mostly with a duration of about one week. No clear peaks were noted in 1998, 2000, and 2002 in the Helsinki area and in 2000 in Tallinn Bay. The normal period for cyanobacterial strong development was mainly restricted to July, while in August they were replaced by or co-dominated with small flagellates (cryptomonads, Pyramimonas, Chrysochromulina, Pseudopedinella, and others). In the cool and rainy summer of 1998, the dinoflagellate Heterocapsa triquetra reached bloom-like concentrations in the central Gulf of Finland.

\section{Nutrient conditions and cyanobacterial blooms}

The internal storage of both nitrogen and phosphorus and their depletion during the cyanobacterial biomass growth is well documented (e.g. Larsson et al., 2001; Walve, 2002). The extremely vigorous blooms in the Gulf of Finland in July 
1997 and 2002 have been associated with excessive inorganic phosphorus released from bottom sediments in preceding autumn and winter as well as its incomplete utilization by the phytoplankton spring bloom (Pitkänen et al., 2003). Considering this, we tried to find relationships between cyanobacterial biomass and the inorganic $\mathrm{N}: \mathrm{P}$ ratio and $\mathrm{PO}_{4}-\mathrm{P}$ and $\mathrm{NO}_{3}+\mathrm{NO}_{2}-\mathrm{N}$ concentrations in the surface layer.

As the first step, two-way ANOVA test was performed to evaluate the variation in the biomass of three main diazotrophic cyanobacteria - Anabaena, Aphanizomenon, and Nodularia - in different locations and years. We could not ascertain the effect of different sampling locations, but for all three species the between-year difference in biomass was significant $(p<0.001$ for Anabaena and Aphanizomenon and $p=0.002$ for Nodularia). Anabaena was discarded from further analysis due to its dominance only in a few samples, and the interactions between nutrient conditions and biomass growth were investigated for the remaining two species. Although the pronounced peak biomass values mainly determined the magnitude of cyanobacterial bloom, we performed multiple regression analysis with seasonal mean (15 June to 31 July) biomass values to mitigate the random effect of uneven spatio-temporal distribution of phytoplankton. Despite the coincidence of the years of cyanobacterial blooms (1997, 1999, 2001, and 2002) and the years of increased pre-bloom phosphate concentrations (1997 and 2002), the relationships between these two parameters were found to be very weak or non-existent (Table 3). Surprisingly, we found a strong positive curvilinear regression $\left(r^{2}=0.82, p<0.001, n=12\right)$ between the pre-bloom inorganic nitrogen $\left(\mathrm{NO}_{3}+\mathrm{NO}_{2}-\mathrm{N}\right)$ concentrations and the biomass of A. flos-aquae (Fig. 4). The data were slightly modified in comparison with those calculated in Table 3 by excluding two sampling values that deviated the most strongly from the defined regression (stations WQ5 and WQ7 in 2002).

Table 3. Coefficients of determination $\left(r^{2}\right)$ between cyanobacterial biomass and nutrient conditions. Pre-bloom values of inorganic N:P ratio, $\mathrm{NO}_{3}+\mathrm{NO}_{2}-\mathrm{N}$, and $\mathrm{PO}_{4}-\mathrm{P}$ are related to mean seasonal biomass values at different stations over the period 1997-2002 (numerator, $n=42$ ) and for 1997 and 2002 (denominator, $n=14$ ). Values with $p<0.05$ are marked with bold

\begin{tabular}{|c|c|c|c|c|c|c|}
\hline & Biomass & $N$. spumigena & A. flos-aquae & $N: P$ & $\mathrm{NO}_{3}$ & $\mathrm{PO}_{4}$ \\
\hline $\mathrm{N}$-fixing cyanobacteria & & $\frac{\mathbf{0 . 4 5}}{0.18}$ & $\frac{0.83}{0.87}$ & $\frac{0.05}{0.28}$ & $\underline{0.01}$ & $\underline{0.03}$ \\
\hline N. spumigena & & & $\frac{0.12}{0.02}$ & $\frac{0.02}{0.00}$ & $\frac{0.05}{0.03}$ & $\frac{0.03}{0.16}$ \\
\hline A. flos-aquae & & & & $\frac{0.02}{0.44}$ & $\frac{0.09}{\mathbf{0 . 4 3}}$ & $\frac{0.07}{0.01}$ \\
\hline $\mathrm{N}: \mathrm{P}$, molar & & & & & $\frac{0.37}{0.95}$ & $\frac{0.16}{0.05}$ \\
\hline $\mathrm{NO}_{3}, \mu \mathrm{mol} \mathrm{L}{ }^{-1}$ & & & & & & $\frac{0.01}{0.11}$ \\
\hline
\end{tabular}




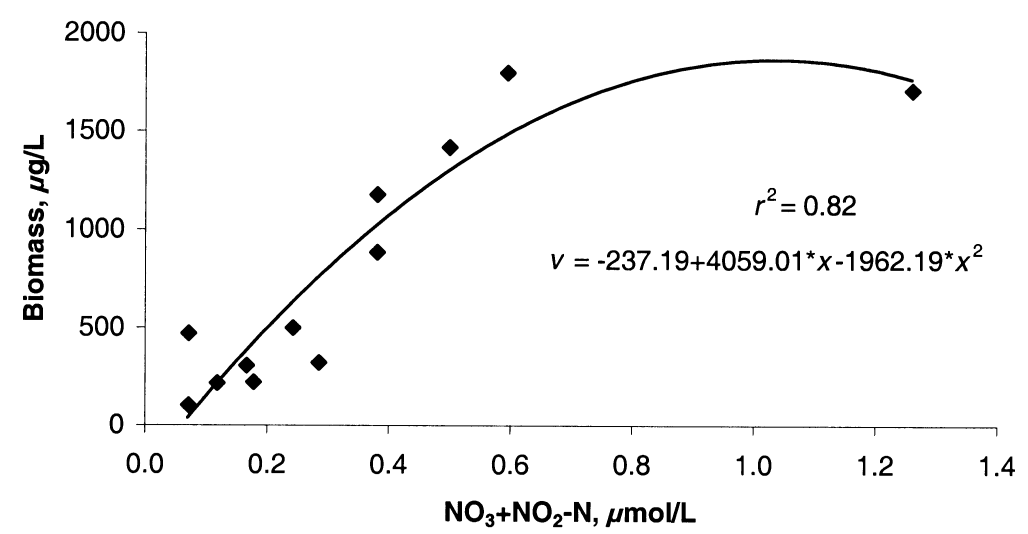

Fig. 4. Wet weight biomass of Aphanizomenon flos-aquae vs. initial concentrations of inorganic nitrogen $\left(\mathrm{NO}_{3}+\mathrm{NO}_{2}-\mathrm{N}\right)$ in 1997 and 2002.

\section{DISCUSSION}

\section{$\mathrm{N}: \mathrm{P}$ ratio}

During summer only small amounts of available nutrients can be found in surface waters. Filamentous cyanobacteria deviate considerably from the Redfield molar ratio $(\mathrm{N}: \mathrm{P}=16: 1)$ during their development. In our study, the $\mathrm{N}: \mathrm{P}$ ratio measured before the cyanobacterial growth period varied generally from 0.3 to 6.9 , and only in 2001 the value exceeded considerably the Redfield number at station WQ1 $(\mathrm{N}: \mathrm{P}=23.2)$. This suggests that summer phytoplankton communities in the central Gulf of Finland are limited by nitrogen, which means that biomass formation of diazotrophic cyanobacteria may be expected. It also means that in a nitrogen-limited environment these algae can overcompete with other planktonic organisms in phosphorus uptake.

At mostly low $\mathrm{N}: \mathrm{P}$ ratios we did not find considerable correlations either with cyanobacterial biomass or with dominating species. A moderate positive correlation was calculated only for A. flos-aquae in years of enhanced bloom activity (1997 and 2002). However, the $N: P$ ratios before the bloom formation were equally low and far from the optimum ratio despite the year and even lower for 1997 and 2002. It is not surprising, since several investigations have proved faster growth of diazotrophic cyanobacteria on ammonium or nitrate as the nitrogen source than when forced to fix nitrogen as the mechanism of molecular nitrogen uptake requires more energy (review by Howarth et al., 1988). Although cyanobacteria have lower optimum N:P ratios compared with other algae (e.g. Rhee \& Gotham, 1980), our conclusions tend to favour the standpoint that if the nutrient conditions are of importance, the concentrations of single elements play a more essential role (see also Downing et al., 2001). It is also shown that the $P$ demand of filamentous $\mathrm{N}_{2}$-fixing cyanobacteria is smaller than expected from Redfield ratio and only a few percent of the remineralized phosphorus is needed for their growth in summer (Larsson et al., 2001). 


\section{Phosphates}

Besides dissolved inorganic phosphorus left over from the spring bloom, several external sources of $\mathrm{P}$ like remineralization of organic matter, turbulent mixing, upwelling, and/or transport by vertical migration from below the summer pycnocline may influence the growth of summer phytoplankton communities (e.g. Kononen, 1992; Kononen et al., 1996). Earlier nutrient addition experiments with natural populations of cyanobacteria in the Gulf of Finland still indicated that the response is not clear, especially for phosphorus (e.g. Kononen et al., 1993). In our material we detected short-term rises in $P$ concentrations in the Helsinki area in 1997-99 (stations WQ1 and WQ3) and also in Tallinn Bay in 1998 (station WQ11), which led to increased N-fixing cyanobacterial abundance. These pulses were, however, not connected to maximum biomass growth of cyanobacteria, which usually occurred during 2-3 weeks after they became dominant in phytoplankton communities. According to field studies of the seasonal variation in nutrient elemental composition of the plankton in the Baltic, the $\mathrm{P}$ content of Aphanizomenon is very high in spring and summer and decreases gradually as the biomass increases in the summer (Walve, 2002). So, the storage of $\mathrm{P}$ in Aphanizomenon biomass is potentially important for the later bloom formation and likely most phosphorus has already been stored in Aphanizomenon biomass at the start of the intensive growth period. A lower P content in the summer was also measured in Nodularia (Larsson et al., 2001; Walve, 2002).

The concentrations of inorganic phosphorus were high in 1997 and 2002 $\left(0.22-0.72 \mu \mathrm{mol} \mathrm{L}^{-1}\right)$, the lowest values were measured in 1999-2001 $(0.06-$ $0.34 \mu \mathrm{mol} \mathrm{L}^{-1}$ ). The total biomass of $\mathrm{N}_{2}$-fixing cyanobacteria comprised mainly two species - A. flos-aquae and N. spumigena. In 1998-2001, their biomass made up $85-100 \%$ of all diazotrophs from 15 June to 31 July. Only in 1997 and 2002 Anabaena spp. contributed up to 32 and $22 \%$ of the biomass of the $\mathrm{N}$-fixing cyanobacteria, respectively. The importance of Aphanizomenon was weightier in cooler summers of 1998 and 2000 (71-95\% of the total diazotrophs) and varied in the range $42-90 \%$ during the rest of the investigation period. Usually the percentage of Aphanizomenon in the phytoplankton biomass was greater in shallow stations (WQ1, WQ3, and WQ11), but in 2002 the absolute maximum was recorded in the central part of the route (station WQ7). Nodularia dominated more sporadically in phytoplankton and its maxima were obtained at different locations in different years (Fig. 3). It is still possible to distinguish clear peaks in the southern part of the gulf in 1999 and in the northern and central parts in 2001, when this species accounted for up to $50 \%$ of total $\mathrm{N}_{2}$-fixing cyanobacteria. From this it is clearly seen that these two species reach the biomass maximum under different conditions. As concerns inorganic phosphorus, we could not find any reliable relations between the nutrient supply and the magnitude of biomass of both dominant species. Moreover, in 1999 and 2001 the initial concentrations of phosphorus were at their lowest in locations where the sharp biomass peaks of Nodularia were recorded (Table 2). 
A field study performed in the Gulf of Bothnia and in Bothnian Bay indicated that the concentration of inorganic phosphorus $<0.06 \mu \mathrm{mol} \mathrm{L}^{-1}$ is too low for saturating growth conditions and for the development of a proper biomass of Nodularia and Aphanizomenon (Andersson et al., 1996). Some other investigations in the Baltic still show that phytoplankton is able to extract nitrates and phosphates to the concentrations as low as $<0.1 \mu \mathrm{mol} \mathrm{L}{ }^{-1}$ (e.g. Wulff \& Rahm, 1988; Fonselius et al., 1989).

\section{Nitrates}

As it appeared from the results, the magnitude of the Aphanizomenon bloom was in a strong correlation with the concentrations of inorganic nitrogen in 1997 and $2002\left(r^{2}=0.82, n=12\right)$. This may indicate that besides phosphorus Aphanizomenon needs also an adequate supply of nitrogen for biomass proliferation. Anyhow, the importance of stored nutrients as residual from spring bloom is greater for Aphanizomenon than for Nodularia, but in mesoscale blooms Aphanizomenon may also benefit from the short-term nutrient pulsing events (e.g. Kononen et al., 1996).

It is interesting that in 1997 and 2002 the concentrations of both inorganic nitrogen and phosphorus increased during a relatively short period at the end of May/beginning of June in the northern and southern parts of the gulf, respectively. In both cases those external nutrient pulses were reflected in mass development of A. flos-aquae (Fig. 3). In 2002 the elevated concentrations of nutrients accompanied the fall in the surface water temperature, probably indicating an upwelling near the southern coast of the Gulf of Finland. This suggests that mass development of cyanobacteria may profit more effectively by a short-term pulse-like nutrient influx than by a surplus from the spring bloom.

Aphanizomenon formed a major part of the cyanobacterial biomass also in the cool and rainy summers of 1998 and 2000, but did not always reach the mass numbers indicating a bloom, especially in coastal stations. The studies along a nutrient gradient at the Swedish coast showed a decrease in Aphanizomenon biomass near the discharge of nitrogen-rich water with suggestions to its low competitive ability with other algae in nitrogen-rich conditions (Wallström, 1988). The absence of summer cyanobacterial maximum observed repeatedly in the Helsinki sea area (station WQ1 in 1998, 2000, and 2002) may thus indicate an increased nitrogen load compared to other stations.

\section{ACKNOWLEDGEMENTS}

We are grateful to an anonymous reviewer for valuable suggestions on the manuscript. This study was inconceivable without kind support from our Alg@line partners in the Finnish Institute of Marine Research, Uusimaa Regional Environment Centre, and Silja Line. We are also grateful to Inga Lips and Kaire Kaljurand for help in phytoplankton and Jonne Kotta in statistical analysis. 


\section{REFERENCES}

Andersson, A., Hajdu, S., Haecky, P., Kuparinen, J. \& Wikner, J. 1996. Succession and growth limitation of phytoplankton in the Gulf of Bothnia (Baltic Sea). Mar. Biol., 126, 791-801.

Downing, J. A., Watson, S. B. \& McCauley, E. 2001. Predicting cyanobacteria dominance in lakes. Can. J. Fish. Aquat. Sci., 58, 1905-1908.

Finni, T., Kononen, K., Olsonen, R. \& Wallström, K. 2001. The history of cyanobacterial blooms in the Baltic Sea. Ambio, 30(4-5), 172-178.

Fonselius, S., Nehring, D., Perttilä, M., Põder, T. \& Weichart, G. 1989. Chemical results of the grid programme of the Patchiness Experiment 1986 in the Baltic Sea. In Proc. 16th Conf. Baltic Oceanogr., Kiel, September 1988, 1, 443-456.

Hecky, R. E. \& Kilham, P. 1988. Nutrient limitation of phytoplankton in freshwater and marine environments: a review of recent evidence on the effects of enrichment. Limnol. Oceanogr., 33, 796-822.

HELCOM. 1988. Guidelines for the Baltic Monitoring Programme for the third stage. Part D. Biological determinands. Baltic Sea Environ. Proc., 27D.

Hillebrand, H., Dürselen, C.-D., Kirschtel, D. Pollingher, U. \& Zohary, T. 1999. Biovolume calculation for pelagic and benthic microalgae. J. Phycol., 35, 403-424.

Horstmann, U. 1975. Eutrophication and mass production of blue-green algae in the Baltic. Finn. Mar. Res., 239, 83-90.

Howarth, R. W., Marino, R. \& Cole, J. J. 1988. Nitrogen fixation in freshwater, estuarine and marine ecosystems. 2. Biogeochemical controls. Limnol. Oceanogr., 33, 688-701.

Kononen, K. 1992. Dynamics of the toxic cyanobacterial blooms in the Baltic Sea. Finn. Mar. Res., 261, 3-36.

Kononen, K., Lahdes, E. O. \& Grönlund, L. 1993. Physiological and community responses of summer plankton to nutrient manipulation in the Gulf of Finland (Baltic Sea) with special reference to phosphorus. Sarsia, 78, 243-253.

Kononen, K., Kuparinen, J., Mäkelä, K., Laanemets, J., Pavelson, J. \& Nõmmann, S. 1996. Initiation of cyanobacterial blooms in a frontal region at the entrance to the Gulf of Finland, Baltic Sea. Limnol. Oceanogr., 41(1), 98-112.

Larsson, U., Hajdu, S., Walve, J. \& Elmgren, R. 2001. Baltic Sea nitrogen fixation estimated from the summer increase in upper mixed layer total nitrogen. Limnol. Oceanogr., 46(4), 811-820.

Niemi, A. 1979. Blue-green algal blooms and N : P ratio in the Baltic Sea. Acta Bot. Fenn., 110, 57-61.

Paerl, H. W. 1997. Coastal eutrophication and harmful algal blooms: importance of atmospheric deposition and groundwater as "new" nitrogen and other nutrient sources. Limnol. Oceanogr., 42 (5, part 2), 1154-1165.

Pitkänen, H., Lehtoranta, J. \& Räike, A. 2001. Internal nutrient fluxes counteract decreases in external load: the case of the estuarial Eastern Gulf of Finland, Baltic Sea. Ambio, 30(4-5), 195-201.

Pitkänen, H., Lehtoranta, J., Peltonen, H., Laine, A., Kotta, J., Kotta, I., Moskalenko, P., Mäkinen, A., Kangas, P., Perttilä, M. \& Kiirikki, M. 2003. Benthic release of phosphorus and its relation to environmental conditions in the estuarial Gulf of Finland, Baltic Sea, in the early 2000s. Proc. Estonian Acad. Sci., Biol. Ecol., 52, 173-192.

Reynolds, C. S., Dokulil, M. \& Padisák, J. 2000. Understanding the assembly of phytoplankton in relation to the trophic spectrum: where are we now? Hydrobiologia, 424, 147-152.

Rhee, G-Y. \& Gotham, I. J. 1980. Optimum N:P ratios and coexistence of planktonic algae. J. Phycol., 16, 486-489.

SFS-EN ISO 13395. 1997. Water quality. Determination of nitrite nitrogen and nitrate nitrogen and the sum of both by flow analysis (CFA and FIA) and spectrometric detection (ISO 13395:1996).

SFS 3025. 1986. Veden fosfaatin määritys. 
Sterner, R. W. 1994. Seasonal and spatial patterns in macro- and micronutrient limitation in Joe Pool Lake, Texas. Limnol. Oceanogr., 39, 535-550.

Wallström, K. 1988. The occurrence of Aphanizomenon flos-aquae (Cyanophyceae) in a nutrient gradient in the Baltic. Kiel. Meeresforsch. Sonderh. 6, 210-220.

Walve, J. 2002. Nutrient limitation and elemental ratios in Baltic Sea plankton. Doctoral dissertation. Department of Systems Ecology, Stockholm University.

Wulff, F. \& Rahm, L. 1988. Long-term, seasonal and spatial variations of nitrogen, phosphorus and silicate in the Baltic: an overview. Mar. Environ. Res., 26, 19-37.

Wulff, F., Stigebrandt, A. \& Rahm, L. 1990. Nutrient dynamics of the Baltic Sea. Ambio, 19, 126-133.

\title{
Kas fosfori liig tingimata põhjustab õhulämmastikku fikseerivate sinivetikate biomassi kasvu?
}

\author{
Andres Jaanus ja Katja Pellikka
}

Tallinna ja Helsingi vaheliselt merealalt 1997-2002 intensiivse seire käigus kogutud materjali põhjal hinnati fosfaatide $\left(\mathrm{PO}_{4}-\mathrm{P}\right)$ suurenenud sisalduse mõju õhulämmastikku fikseerivate sinivetikate biomassile ja liigilisele domineerimisele. Fütoplanktoni biomassi mõõdeti nädalase intervalliga 15. juunist 31. juulini ja tulemusi suhestati kevadõitsengust alles jäänud toitainete kontsentratsioonidega. Olulist seost fosfaatide sisalduse ning lämmastiku ja fosfori suhte $(\mathrm{N}: \mathrm{P})$ ning sinivetikate biomassi taseme vahel ei leitud. Aastatel 1997 ja 2002 põhjustas liigi Aphanizomenon flos-aquae vohamise tõenäoliselt süvavee kerke ja/või teiste hüdrodünaamiliste protsessidega kaasnenud lühiajaline lämmastiku- ja fosforiühendite sisalduse tõus. Nodularia spumigena massesinemised aastatel 1999 ja 2001 olid lokaalsed ja lühiajalised, samas fosfaatide kontsentratsioonid jäid miinimumtasemele $(<0,1 \mu \mathrm{M})$. Seega määravad sinivetikate õitsengute ulatuse ja intensiivsuse pigem soodsad toitumistingimused vahetult enne õitsengut kui kevadest järele jäänud toitained. 